\title{
Headlines
}

\section{Companies worldwide moving swiftly to adopt stock option programmes}

\author{
Compiled and written by Towers Perrin in June 2001
}

\section{International}

\section{Stock options are becoming an increasingly prevalent feature of long-term incentive (LTI) programmes in company pay plans worldwide, according to a new study by Towers Perrin.}

While LTI plans have been almost universal among US, UK and Canadian companies since 1997, companies elsewhere are now moving swiftly to make stock options a key component of total pay. This growing appeal of linking at least some part of employee compensation to a company's stock price no doubt reflects the increasingly powerful influence of global capital markets, as well as the success of these programmes at many leading multinationals.

The research indicates that between now and 2003, under conditions that will vary according to local market practice, Argentina, Germany, Italy and Spain are expected to show a 50 per cent increase in LTI programmes. Additionally, the number of programmes in place is expected to double in South Korea and more than triple in Mexico and Japan.
The Towers Perrin study, Stock Options Around the World, documents the rapid worldwide growth of stock option plans by examining the practices of large local companies headquartered in 22 different countries. Findings show that in most countries, regardless of the type of company, stock options are more widely used than performance plans, restricted stock plans and other LTI programmes.

By 2003, most large, local companies around the world are expected to have some type of long-term incentive programme primarily driven by stock options. The trend means that companies doing business in international markets will have to restructure employee compensation strategies and place emphasis on LTIs to remain competitive. As a result, more employees will become eligible for stock options as companies see the value of these plans and lower the thresholds for participation.

In countries with a history of stock options and share ownership, such as the US, UK and Canada, stock options lost much of their perceived value during the recent bear market, diluting the effectiveness of these plans as a way to drive employee behaviour to support 
business strategy. In other countries with no tradition of share ownership, cultural norms that influence attitudes toward risk and the way unfamiliar forms of remuneration are perceived can make the implementation of global stock options particularly challenging. Different messages are required for different countries if employees are expected to understand the rationale behind stock options and act accordingly.

\section{Award practices vary}

While stock options are granted to employees typically once a year, vesting schedules and the term, or duration, of a grant are often driven by legal and tax rules that vary from one country to another. The typical term for option grants in the US and UK is ten years, while grants in other countries such as Australia, Belgium, Brazil, Germany and Spain often have terms varying from five to ten years. While most executives do not hold their options for the entire term, options nonetheless give companies a powerful retention tool that they can design to suit their needs by mixing the vesting, term and frequency of the grants.

Patterns determining eligibility criteria for stock options vary widely among countries, but there appears to be a roughly even distribution between awards by position and by reporting level. Grants awarded at the discretion of senior management appear less prevalent than a few years ago, with most companies applying several guidelines to make grants, rather than using reporting level or position as the sole criterion.

\section{Local conditions are key}

Employers will have to monitor the constantly changing local regulations and market practices in countries where they have operations in order to retain consistency with global plan designs and objectives, according to the report.
Among the critical local issues that must be considered and readdressed in the light of local law changes and public issues is share utilisation, which indicates how much of a company's total outstanding shares can be set aside for stock options. Another important issue is taxation, a critical element of plan design. Most stock options are taxed at ordinary tax rates, ranging from 15 per cent in Hong Kong to 60 per cent in Belgium, with the actual rate for individuals depending on a number of factors.

Copies of the Stock Options Around the World study can be obtained by contacting your nearest Towers Perrin office.

Further information: Damian Carnell (carneld@towers.com), London, +44-20-7806-6440, or Fabrizio Alcobe-Fierro (alcobef@towers.com), New York, +1-212-309-3748.

\section{Argentina}

\section{Reforms change structure of employment contracts}

The Argentine government has implemented reforms which mean that, in future, employers may negotiate labour contracts with their local workforce rather than with national unions.

The law, part of the ongoing reform and deregulation of the Argentine economy, was passed last year. It is aimed at increasing the mobility and flexibility of the labour market and decentralising collective bargaining. Specifically, the law:

— ends national unions' exclusive rights to negotiate with employers, leaving employers to negotiate with local unions and labor committees made up of their own workers 
- ends the system whereby the union and employer had to agree on the terms of a new employment contract before the old one could expire

- cuts, by 33 per cent, social security payments for new hires who increase the total headcount of a company (the reduction increases to 50 per cent when the new hire is older than 45 , younger than 24 or a housewife) and reduces the bureaucracy associated with new hires

- extends the probation period for new hires from one month to three

- requires companies with 500 or more workers to prepare an annual 'Social Balance' report for unions to provide information on activities that could significantly alter employment and working conditions in the future.

Further information: Eduardo Cortes (cortese@towers.com) Buenos Aires, +11 4131 2555, or Zoltan Rosenfeld (rosenfz@towes.com), Buenos Aires, +11 41312554.

\section{Australia}

\section{Budget includes tax reliefs for retirees}

The Australian federal budget announced on May 22 contains measures to reduce taxes on lower income retirees.

Specifically, it includes:

- introduction of a tax free threshold for self-funded retirees of $\$ 20,000$ for individuals and $\$ 32,612$ for couples. The new threshold is retroactive to 1st July, 2000 and applies only to those older than the eligibility age for the means tested age pension, and is achieved through a tax rebate

- relief from tax surcharges paid by individuals who receive Eligible Termination Payments (ETPs) from their employer.
Further information: Steve Schubert (schubes@towers.com), Melbourne, +61392708250.

\section{Belgium}

\section{Draft law will prompt big changes in pension plans}

Belgian employers will need to look at the way they provide retirement and death benefits to their employees in the light of new draft pension legislation which significantly affects pension provision in Belgium.

The provisions of the draft include:

- creation of a framework for industry-wide pension plans (which employers may or may not be obliged to participate in, depending on their sector)

- introduction of a new type of plan called a 'Social Plan' which will have some advantages over regular plans, including an exemption from the 4.4 per cent premium tax on contributions

- a requirement for defined contribution (DC) and cash balance plans to provide a minimum rate of return of 3.25 per cent (or inflation if payment occurs within first five years) on annual employer contributions, in addition to the existing guarantee of 3.75 per cent on employee contributions

- a requirement to send annual statements to deferred members

- taxation of pension and lump sum benefits to be equalised, with some minor exceptions

- allowing individual pension promises only at the moment of the first employment contract with the employer and employee, thus eliminating discretionary benefit improvements toward the end of an 
individual's career (eg, 'golden

handshakes');

- elimination of pension plan formulas that result in a zero benefit for any participating employees

- prohibition against benefit payments before the age of 60 - a provision which will probably be finalised in some less restrictive way.

Employers running DC plans must ensure that they comply with the requirement for a minimum rate of return on employee and employer contributions. One of the results of this change may be that such plans will be classed as DB under FAS 87.

Employers sponsoring DB plans will have to ensure that their plan provides final benefits for all members. For example, plans that only provide benefits above the social security ceiling will have to be adjusted.

The draft legislation is currently under discussion. It is expected to pass through Parliament very soon.

Further information: Gret'hl Van Hoyweghan (hoywegg@towers.com), Brussels, +2 7758438 .

\section{Brazil}

\section{New law modernises private pensions}

A new private pensions law, overhauling the Brazilian pension system and introducing a raft of reforms, looks set to revitalise the Brazilian pension market.

The new law was approved by Congress on 25th April, 2001 and submitted to the president for signature and immediate enactment. It replaces a 23 year-old law.

Details of how the legislation will work are expected to be released through regulations over the coming months. Important features of the new law include the following:
- unions, associations and similar organisations will now be able to set up and sponsor pension plans, whereas before only employers could do thisa change that is expected to bring millions of workers into the private pension system

- plan investment returns will no longer be taxed, only benefits

- the government will be prohibited from setting mandatory minimum investments in specific asset classes such as Treasury bills

- employees will be able to transfer their pension funds between plans when changing employer, and between insured plans and trust-based plans

- there will be mandatory vesting of employer contributions (previously employers were able to assert a right to all company contributions).

Forthcoming regulations are expected to specify whether this vesting will be retroactive.

It has been estimated that the measures in this new law will boost private pension savings from 11 per cent of GNP to around 40 per cent in the next ten years. Brazilian companies should examine their benefit structures in light of this new law and decide how to make the appropriate changes.

Further information: Eder Carvalhaes (carvale@towers.com), Sao Paulo, +55 1141312500.

\section{Canada}

\section{Court ruling could force distributions to employees}

Employers could be forced to distribute surplus to employees on the partial wind up of their pension plan following a ruling by the Ontario Divisional Court. If the decision is upheld, it could have 
serious implications for well funded plans with members in Ontario, regardless of where the plans are actually registered.

On 19th March, 2001, the Divisional Court ruled that Monsanto was required to distribute that portion of its plan's surplus that was attributable to the members affected by the partial wind up (employers are already required to distribute surplus when the entire plan winds up). This decision reversed the ruling of the Financial Services Tribunal, which had found that there was no legislative requirement to distribute surplus on a partial wind up.

Monsanto has now asked to appeal the decision to the Court of Appeal. The Association of Canadian Pension Managers and the National Trust, which both joined the proceedings as interested parties, have also sought appeal.

There have been approximately 210 partial wind up reports filed in Canada since 1992. This ruling could affect any of them, and even those reports filed earlier.

Employers who are either considering or processing the partial wind up of a plan where there is significant surplus should proceed with great caution until the result of this application to appeal, and any subsequent trial, are known.

Further information: Kevin Aseltine (aselstk@towers.com), Toronto, +1 416 960 2712, Michael Millns (millnsm@towers.com), Toronto, +1416 9607114 or Priscilla Healy (healyp@towers.com), Toronto, +1 416 9602850.

\section{European Union}

\section{Commission to challenge obstacles to pan-European pensions}

The European Commission has said it intends to take member states to the European Court of Justice (ECJ) in order to force them to remove tax obstacles to pan-European pensions.

The statement came in a communication that set out the Commission's views on the taxation by member states in the pension plans of other member states. Specifically, the Commission:

— recognised the burden on pan-European multinationals through having to set up a separate plan in each country in which they operate, and the huge potential advantage in sponsoring one single pan-European plan

- stated that discriminatory treatment of cross-border plans was in breach of existing EU law (a view of many commentators for some time).

The Commission will now attempt to force the tax authorities of the various member states to comply with this interpretation of the law by taking them to the ECJ, where it believes that their practices against membership in cross border plans will be ruled discriminatory.

Such action is not to be taken lightly - it will take time and will face the argument that national sovereignty over tax affairs overrules anything in the EU treaties. Nonetheless, there is now a real possibility of pan-European pensions becoming a reality, and this possibility should be factored into the strategic planning of multinationals operating in European countries.

Further information: Tony Bacon (bacont@towers.com), London, +44020 88953889.

\section{Germany}

\section{Pension reform to proceed}

Employers should re-examine their benefits structure following the German 
parliament's approval of pension law reforms, especially those allowing tax incentives for funded plans.

On 11th May, 2001, the upper house of the German parliament finally approved the long awaited measures for reform of the pension system. These new measures mean that:

- the state pension will be decreased with the introduction of a modified pension indexation formula

- employees will be able use funded vehicles to accumulate additional retirement income, supported by a subsidy and/or tax deduction starting at 1 per cent of earnings up to the social security ceiling (rising to 4 per cent by 2008).

- employers will be able to provide funded pension plans through these new approaches or through a captive insurance arrangement (Pensionskasse) without triggering employee tax on contributions of up to 4 per cent of the social security ceiling, starting in 2002.

Key features of the new pension funds permit:

— funded defined benefit or defined contribution options, guaranteeing a minimum benefit

- greater investment flexibility than insurance company funds

- transfers from existing, book reserved, pension entitlements without incurring tax.

Existing employer plans will also be affected in several ways:

- employees will have the right to pay contributions (to new or old style funds) via salary reduction;

— improved vesting rules will mean that company-financed plans will now have a maximum vesting period of age 30 and five-year membership (previously age 35 and ten years) while employee-financed plans will vest immediately.

— indexation will be required for certain types of plan.

Employers should:

- ensure that their existing retirement arrangements comply with the new rules

- examine the new funded vehicles, and decide if they should take advantage of one of the potential new structures

- satisfy themselves that their member communication strategy will keep their employees adequately informed about the reforms.

Further information: Dorit Brandt (brandtd@towers.com), Frankfurt, +69-1505-5225.

\section{Japan}

\section{Ongoing reforms bring HR opportunities}

While the Japanese economy still contains rigidities, the employment environment has become more liberal recently, making this an excellent time to introduce $\mathrm{HR}$ changes.

The pace of structural reform driven by business necessity, deregulation and shareholder pressure - is accelerating and has resulted in increased bankruptcies, restructuring and M\&A deals. The most recent changes include the liberalisation of security transaction and foreign exchange laws, the introduction of holding companies, the introduction of stock options, the easing of restrictions on competition in several sectors, and revisions to the Labor Standards Law. 
Some of the changes which directly affect HR are detailed below.

\section{Corporate governance}

Governance is being improved by making boards smaller and more accountable, and through the establishment of stock option plans and executive compensation committees. Outside director appointments remain rare but are expected to increase.

\section{Corporate law}

Legislation to facilitate spin-offs and acquisitions is expected to be introduced soon. Together with related tax incentives, this should encourage merger and restructuring activity.

\section{Stock options}

Since the prohibition on stock options was ended in 1997 over 500 companies have set up plans. Currently, however, total grants are limited to 10 per cent of outstanding shares and $10 \mathrm{~m}$ Yen

(US\$83,300) per person per year. These restrictions are expected to be removed by the end of 2001 along with the requirement for shareholder authorisation of new plans.

\section{Stock ownership plans}

Legislation is being considered to provide favourable treatment of stock ownership plans. The approach will likely favour tax deductible contributions with taxation deferred until distribution.

\section{Pension accounting}

New rules for defined benefit pension accounting (ACR13), similar to IAS19, took effect on 1st April, 2000. Due to a requirement in the new rules to use a discount rate based on high quality corporate and government bonds, recent valuations have used discount rates as low as 2.5 per cent and resulted in increases to expenses and liabilities.
Nonetheless, the statutory method for determining plan contributions has been retained, resulting in significant differences between accounting expense and actual cash flow into plans

\section{Defined benefit legislation}

A bill to create a new defined benefit framework is due for submission. It aims to:

- allow employers which have established contracted-out Employee Pension Funds (EPFs) to convert them to regular funded plans

- provide greater protection for members' benefits through tighter funding requirements, increased disclosure and requiring consultation on plan changes.

\section{Defined contribution legislation}

This bill has been submitted to the current Diet session. If passed, defined contribution plans should be available before the year end that will:

- limit annual employer contributions to 432,000 yen per employee if the employer provides no other funded retirement plan, or 216,000 yen if it does

- prohibit employee contributions

- pay benefits on death, disability or retirement

- require full vesting after three years

- allow member accounts to be rolled over to a new employer's plan

- allow investment in equities, bonds and cash deposits.

Separate regulations will apply to individual plans where there is no employer.

\section{Labour standards law}

The recent labour standards law has led to greater employee protection as well as 
increased flexibility. The changes

introduced include:

- maximum duration of fixed-term contracts increased from one to three years

- more extensive disclosure requirements for employment terms

- extension of 'deemed' work hours (in lieu of overtime)

- abolition of overtime restrictions on female staff

- employee right to a certificate stating the reasons for the termination of employment

- higher minimum days vacation

- provision of employee requested leave for family health care.

Further information: Tetsuo Tohno (tohnot@towers.com), Tokyo, +3 3581 6433 or Gerry Williams (williag@towers.com), Tokyo, +3 3581 6434.

\section{Malaysia}

\section{Employees' minimum contribution temporarily cut from 11 per cent to 9 per cent}

Employers may wish to satisfy themselves that employees are aware of the implications of a reduction to the minimum employee contribution level for the Employees Provident Fund (EPF).

The cut from 11 per cent to 9 per cent of pay is intended to increase the disposable income of individuals in response to the economic slowdown from the sharp decline in exports to the USA.

- employees may still contribute up to a maximum of 12 per cent if they wish

- employers must still contribute a minimum of 12 per cent to the fund.
The changes are in line with the government's proactive approach to revive economic growth.

Further information: Mohamed Hazleen (hazleem@towers.com), Kuala Lumpur, +6132365147.

\section{Netherlands}

\section{New rules will allow employees to buy annual leave}

Employers must consider the implications of new rules that allow employees to purchase and save additional leave.

The Dutch government has introduced a new law which allows employees to save up to 10 per cent of their annual salary in a special account and then later convert it to extra leave. Leave can be saved for in this way by either:

- purchasing the extra leave from salary - sacrificing and saving leave directly.

An individual who chooses to exercise either option must still pay social insurance on the time or salary saved, but tax is deferred until the saved leave is actually taken. The rules stipulate that:

- employer and employee must come to an agreement in respect of how the arrangement will work (a 'leave agreement')

- if an employer chooses to set up a plan under the new rules, at least three-quarters of its employees must be given the chance of joining

- the amount of leave saved by an individual must not exceed the amount necessary to pay gross annual salary for 12 months (ie, allow them to take 12 months off)

- the money representing the saved leave must be deposited with a third party (e.g., a financial institution) in the employee's name 
- the leave cannot be taken in the year before the employee's retirement.

Regulations to detail the withdrawal of saved leave and the possibility of a benefit transfer upon switching employers are now expected.

Employers who take advantage of this new rule should ensure that they agree with employees on how pension and other benefits are affected by periods of leave and ensure that these agreements are documented.

Further information: Adrienn Pasztor (pasztoa@towers.com), Amsterdam, +31-20-711-4113.

\section{Singapore}

\section{New supplementary plan is launched}

Employees have opportunities to increase their retirement savings on a tax efficient basis now that the government has approved a new savings vehicle.

On 1st April, 2001, the Singapore government launched the Supplementary Retirement Scheme ('SRS'), a new type of supplementary pension designed to complement the current Central Provident Fund (CPF). The new vehicle is designed in response to Singapore's ageing population and the low replacement ratios for individuals at retirement, particularly those who are well paid.

The SRS will be voluntary, tax advantaged and financed by employee contributions. It will:

- have the same salary caps on contributions as the $\mathrm{CPF}$

- enjoy tax relief on contributions, investment returns and 50 per cent of withdrawals on retirement

- have a maximum contribution rate of 15 per cent for Singaporeans and Singapore Permanent Residents and
35 per cent for foreigners (who currently do not enjoy tax relief on their contributions to the CPF) - have penalties for early withdrawal.

In contrast to the CPF, the new fund will provide members with a wide range of potential investment options. Only approved providers - there are currently four - will be allowed to offer SRS products.

Further information: Rajesh Daswani (daswanr@towers.com), Singapore, 439 2626.

\section{United Kingdom}

\section{The Minimum Funding Requirement is to be abolished}

Employers and trustees of defined benefit plans should re-examine their investment strategy after the government's announcement that it intends to abolish the statutory Minimum Funding Requirement (MFR) for occupational pension plans.

In his budget on 6th March, 2001, Chancellor of the Exchequer Gordon Brown announced that the Government was to accept all the recommendations of the Myners report on institutional investment, which had been published the day before. In addition to covering investment issues, the report recommended replacing the MFR with plan-specific funding standards. Specifically, the report called for the following new measures:

- trustees will have to draw up and adopt a long-term funding standard specific to their individual plan

- funding deficits against a plan's funding standard will have to be met within a short period, perhaps three years.

- plan actuaries will have a statutory duty to care for members 
— if a plan winds up, employers will have to ensure that benefits are met in full

- plans will have stronger transparency and disclosure requirements.

The new plan-specific funding standards will be drawn up by trustees on the advice of plan actuaries and, because both trustees and Scheme Actuaries will be legally obliged to act in the best interests of members, there may be implications for the degree of employer control over plan funding.

Employers should assess the difference between their current funding policy and the potential funding policies that may result from the new measures and, then assess the financial implications that arise.

The removal of the MFR will require new primary legislation. There has, as yet, been no timetable given for this, or for the implementation of the replacement measures. The Government will now consult with the pensions industry about the details of the new regime.

Further information: Mike Hammer (hammerm@towers.com), London, +44 2088953586. 